\title{
Impact of Financial Variables on Share Price of Selected Indian Automobile Companies
}

\author{
Rakesh Kumar, Ayushman, Rishika Agarwal
}

\begin{abstract}
This study has been conducted to analyze and compare the impact of financial variables on share price of Indian automobile companies. Companies have been selected on the basis of market capitalization. Secondary data has been considered for this study. Secondary data has been collected from annual reports of companies for the financial years 2013-14 to 2017-18 and share prices from the website of Bombay Stock Exchange. Impact has been examined with the help of correlation and regression. Findings of this study shows that Maruti Suzuki India Ltd. share price has been affected by the financial variables. In case of other companies impact of financial variables on share price vary from companies to companies. It has also been found out that there is no significant impact of assets turnover ratio on share price of all selected automobile companies.
\end{abstract}

Keywords: Automobile companies, Financial Ratio, Financial Variable, Share Price.

\section{INTRODUCTION}

The framework of corporate and financial sector is precarious, especially the disparity in the micro and macro financial variables and it's repercussions on capital market, therefore firms stress more on stock market policies because investment decisions require a lot of caution. Variation in micro financial variables unfavorably influences business by disturbing the propensity of trade easiness. Therefore, the forecasting of stock market determinants play a very important role. The success of the firm is directly related with national economy and many firms today are influenced by the speculation of the world as a result of globalization. The overall economic speculation and counter cyclic sensitivity of the company's sector is important, therefore it becomes necessary to identify all possible factors on stock movements.

The factors affecting stock prices are often debatable as share prices change on daily basis. Economists and financial market participants hold contrasting perspective as far as market share prices and variations are concerned. The factors responsible for the variations are divided into two parts, namely, fundamental/internal factors and

Revised Manuscript Received on February 12, 2020.

* Correspondence Author

Dr. Rakesh Kumar*, Department of Accountancy \& Law, Dayalbagh Educational Institute (Deemed University), Agra, India. Email: rakeshyadav301@gmail.com

Ayushman, Department of Accountancy \& Law, Dayalbagh Educational Institute (Deemed University), Agra, India. Email: iamayushman@outlook.com

Rishika Agarwal, Department of Accountancy \& Law, Dayalbagh Educational Institute (Deemed University), Agra, India. Email: rishikaag03@gmail.com

(c) The Authors. Published by Blue Eyes Intelligence Engineering and Sciences Publication (BEIESP). This is an open access article under the CC BY-NC-ND license (http://creativecommons.org/licenses/by-nc-nd/4.0/) non-fundamental/external factors. Fundamental/ internal factors include dividend policy, Earnings Per Share (EPS), investment, assets, performance of the company, debt, creation of new assets, etc., whereas non fundamental/external factors include economy, Gross Domestic Product (GDP), inflation, money supply, government rules and regulations, investors' behavior, competition, market conditions, natural environment and other economic conditions.

Financial Variables : The factors or variables used for forecasting the financial events of the upcoming time and affect the share prices of the company.

Current Ratio : The current ratio, also known as the working capital ratio, measures the capability of a business to meet its short-term obligations that are due within a year.

Assets Turnover Ratio : The assets turnover ratio is an efficiency ratio that measures a company's ability to generate sales from its assets.

Debt Ratio : Debt ratio, a solvency ratio that shows the ability of a company to pay off its total liabilities or debts with its total assets.

Net Profit Ratio : Net profit ratio is a profitability ratio used to calculate the company's profit percentage yield from its total sales.

Book Value per share : It compares the shareholders' equity (excluding preferred shares) amount to the total number of outstanding equity shares.

\section{REVIEW OF LITERATURE}

Agirman and Yilmaz (2018) investigated whether financial ratios can predict stock returns for the period between from 2004: II and 2014: IV in the Borsa Istanbul (BIST) and concluded that firm size has a higher predictive power than dividend per share and price to book ratio respectively. However, there is no significant relationship between price to earnings ratio and stock returns.

Kamar (2017) investigated the effect of Return on Equity (ROE) and Debt to Equity Ratio (DER) on Stock Price on Cement Industry Listed in Indonesia Stock Exchange in the year of 2011-2015. The result of the study shows that Return on Equity (ROE) has significant effect on the stock price, and Debt to Equity Ratio (DER) has effect but not significant on stock price.

Meriç et al. (2017) analyzed the relationships between stock price, Price Earnings (PE) ratio and Dividend Yield (DY) ratio of the banks listed at BIST Banking sub-sector and concluded that variables changes in size and direction from bank to bank. 


\section{Impact of Financial Variables on Share Price of Selected Indian Automobile Companies}

Lutfi and Arsitha (2016) analyzed the effect of factors affecting price earnings ratio on the shares registered in Jakarta Islamic Index. F-test and T-test were used for analyzing the data and the results of the study revealed that Total Assets and Debt to Equity ratios have significant effect to Price Earnings Ratio on the shares registered in Jakarta Islamic Index.

Wijaya (2015) studied the influence of financial ratios toward stock returns in Indonesian manufacturing companies and concluded that return on assets, debt to equity, dividend yield, earnings yield, and book to market simultaneously have a significant effect on stock returns.

Haque et al. (2013) attempted this study to identify the variables that significantly influence the share prices for guiding the investors to select right investment option and concluded that cash flow per share, price-earnings ratio and return on assets significantly impact the share prices and are best metrics for explaining the movements of share price in capital market.

Saeidi and Okhli (2012) investigated the assets return rate impact on stock prices of the companies accepted in Tehran stock exchange and the findings of the study indicate a strong impact and relationship between assets return rate and stock prices.

\section{NEED OF THE STUDY}

It has been observed that previous studies were based on impact of micro variables and financial variables on share price. These studies were conducted in foreign countries as well as in India and the impact has been examined on different sectors but no study has been conducted on automobile sector with reference to impact of financial variables on share price. Therefore this study "Impact of Financial Variables on Share Price of Selected Indian Automobile Companies" have been taken into consideration. Meanwhile this study will guide the investors who wants to invest in the automobile sector. And this study will also help to know whether investor should consider or not the financial variables while investing in the stock market.

\section{OBJECTIVES OF THE STUDY}

1) To analyze the impact of financial variables on share price of selected Indian automobile companies.

2) To compare the impact of financial variables among selected Indian automobile companies.

\section{RESEARCH METHODOLOGY}

\section{A. Sample Size \& Selection Criteria :}

Four Automobile companies have been taken for the purpose of this study namely, Maruti Suzuki India Ltd., Mahindra \& Mahindra Ltd., Hero MotoCorp Ltd. and Tata Motors Ltd. and the selection have been done on the basis of market capitalization as on $1^{\text {st }}$ April, 2018.
Table- I : Market Capitalization of Automobile Companies

\begin{tabular}{|c|c|l|c|}
\hline $\begin{array}{c}\text { Sl. } \\
\text { No. }\end{array}$ & $\begin{array}{c}\text { Scrip } \\
\text { Code }\end{array}$ & \multicolumn{1}{|c|}{ Company } & $\begin{array}{c}\text { Market } \\
\text { Capitalization } \\
\text { (Rs. in Crores) }\end{array}$ \\
\hline 1 & 532500 & Maruti Suzuki India Ltd. & $2,23,839.81$ \\
\hline 2 & 500520 & Mahindra \& Mahindra Ltd. & $92,711.08$ \\
\hline 3 & 500182 & Hero MotoCorp Ltd. & $58,235.16$ \\
\hline 4 & 500570 & Tata Motors Ltd. & $52,621.93$ \\
\hline
\end{tabular}

Source : www.bseindia.com

\section{B. Duration of the Study}

The duration of this study is five financial years that is from 2013-14 to 2017-18.

\section{Data Collection}

Share price data has been collected from data stream of Bombay Stock Exchange (BSE) and the financial variables data has been collected from the official websites of the companies and annual reports.

\section{Analysis Tools}

Researcher has used descriptive and inferential statistics like Average, Standard Deviation and Regression. The tools have been selected as per the nature of data.

\section{HYPOTHESES}

$\mathbf{H}_{01}$ : There is no significant impact of net profit margin on share price.

$\mathbf{H}_{02}$ : There is no significant impact of assets turnover ratio on share price.

$\mathbf{H}_{03}$ : There is no significant impact of debt ratio on share price.

$\mathbf{H}_{04}$ : There is no significant impact of current ratio on share price.

$\mathbf{H}_{05}$ : There is no significant impact of book value on share price.

\section{ANALYSIS AND INTERPRETATION}

A. Impact of Net Profit Margin on Share Price of Selected Automobile Companies :

Table- II : Result of Correlation for Net Profit Margin and Share Price

\begin{tabular}{|l|c|c|c|c|}
\hline Company & $\begin{array}{c}\text { Maruti } \\
\text { Suzuki } \\
\text { India } \\
\text { Ltd. }\end{array}$ & $\begin{array}{c}\text { Mahindra } \\
\text { \& } \\
\text { Mahindra } \\
\text { Ltd. }\end{array}$ & $\begin{array}{c}\text { Hero } \\
\text { MotoCorp } \\
\text { Ltd. }\end{array}$ & $\begin{array}{c}\text { Tata } \\
\text { Motors } \\
\text { Ltd. }\end{array}$ \\
\hline $\mathbf{R}$ & .922 & .961 & .736 & .612 \\
\hline R Square & .851 & .924 & .542 & .374 \\
\hline $\begin{array}{l}\text { Adjusted R } \\
\text { Square }\end{array}$ & .801 & .899 & .390 & .061 \\
\hline $\begin{array}{l}\text { Significance } \\
\text { Value }\end{array}$ & .026 & .009 & .156 & .388 \\
\hline F value & 17.08 & 36.701 & 3.55 & 1.195 \\
\hline
\end{tabular}

Source: Author's Computation

$\mathrm{H}_{01}$ : There is no significant impact of net profit margin on share price. 
Table II states that Maruti Suzuki India Ltd. and Mahindra \& Mahindra Ltd. share prices and net profit margin have highly positive correlation and at the same time there is also a positive correlation between share prices and new profit margin of Tata Motors Ltd. and Hero MotoCorp Ltd. Significance value shows that share price of Maruti Suzuki India Ltd. and Mahindra \& Mahindra Ltd. have impact of net profit margin (Hypothesis rejected), but there is no significant impact of net profit margin on share price of Tata Motors Ltd. and Hero MotoCorp Ltd. (Hypothesis accepted).

On the basis of above result, it can be said that share price of the automobile companies has a noteworthy impact of the profitability of the companies but the degree of impact vary from company to company.

B. Impact of Assets Turnover Ratio on Share Price of Selected Automobile Companies :

Table- III : Result of Correlation for Assets Turnover Ratio and Share Price

\begin{tabular}{|l|c|c|c|c|}
\hline Company & $\begin{array}{c}\text { Maruti } \\
\text { Suzuki } \\
\text { India } \\
\text { Ltd. }\end{array}$ & $\begin{array}{c}\text { Mahindra } \\
\text { \& } \\
\text { Mahindra } \\
\text { Ltd. }\end{array}$ & $\begin{array}{c}\text { Hero } \\
\text { MotoCorp } \\
\text { Ltd. }\end{array}$ & $\begin{array}{c}\text { Tata } \\
\text { Motors } \\
\text { Ltd. }\end{array}$ \\
\hline $\mathbf{R}$ & .285 & .222 & .283 & .183 \\
\hline R Square & .081 & 0.49 & .57 & .034 \\
\hline $\begin{array}{l}\text { Adjusted R } \\
\text { Square }\end{array}$ & -.225 & -.268 & -.258 & -.289 \\
\hline $\begin{array}{l}\text { Significance } \\
\text { Value }\end{array}$ & .643 & .720 & .700 & .768 \\
\hline F value & .264 & .156 & .180 & .104 \\
\hline
\end{tabular}

Source : Author's Computation

$\mathrm{H}_{02}$ : There is no significant impact of assets turnover ratio on share price.

Table III states that there is very low positive or neglected correlation among assets turnover ratio and share price of all the companies. Significance value also concludes that there is no significant impact of assets turnover ratio on share price of all the selected automobile companies. (Hypothesis accepted in case of all companies)

C. Impact of Debt Ratio on Share Price of Selected Automobile Companies :

Table- IV : Result of Correlation for Debt Ratio and Share Price

\begin{tabular}{|l|c|c|c|c|}
\hline Company & $\begin{array}{c}\text { Maruti } \\
\text { Suzuki } \\
\text { India } \\
\text { Ltd. }\end{array}$ & $\begin{array}{c}\text { Mahindra } \\
\text { \& } \\
\text { Mahindra } \\
\text { Ltd. }\end{array}$ & $\begin{array}{c}\text { Hero } \\
\text { MotoCorp } \\
\text { Ltd. }\end{array}$ & $\begin{array}{c}\text { Tata } \\
\text { Motors } \\
\text { Ltd. }\end{array}$ \\
\hline R & .926 & .827 & .506 & .078 \\
\hline R Square & .857 & .684 & .256 & .006 \\
\hline $\begin{array}{l}\text { Adjusted R } \\
\text { Square }\end{array}$ & .715 & .579 & -.487 & -.325 \\
\hline $\begin{array}{l}\text { Significance } \\
\text { Value }\end{array}$ & .024 & .084 & .662 & .901 \\
\hline F value & 6.016 & 6.05 & .345 & .018 \\
\hline
\end{tabular}

Source : Author's Computation

$\mathrm{H}_{03}$ : There is no significant impact of debt ratio on share price.

Table IV states that Maruti Suzuki India Ltd. share price and debt ratio has highly positive correlation and there is also a positive correlation between the share price and debt ratio of Tata Motors Ltd., Hero MotoCorp Ltd. and Mahindra \& Mahindra Ltd. Significance value shows that share price of Maruti Suzuki India Ltd. has an impact of the debt ratio (Hypothesis rejected) but there is no significant impact of debt ratio on share price of Tata Motors Ltd., Hero MotoCorp Ltd. and Mahindra \& Mahindra Ltd. (Hypothesis accepted).

On the basis of above results, it can be said that share price of automobile companies has significant impact of debt ratio of the companies but the degree of impact vary from company to company.

D. Impact of Current Ratio on Share Price of Selected Automobile Companies :

Table- V : Result of Correlation for Current Ratio and Share Price

\begin{tabular}{|l|c|c|c|c|}
\hline \multicolumn{1}{|c|}{ Company } & $\begin{array}{c}\text { Maruti } \\
\text { Suzuki } \\
\text { India } \\
\text { Ltd. }\end{array}$ & $\begin{array}{c}\text { Mahindra \& } \\
\text { Mahindra } \\
\text { Ltd. }\end{array}$ & $\begin{array}{c}\text { Hero } \\
\text { MotoCorp } \\
\text { Ltd. }\end{array}$ & $\begin{array}{c}\text { Tata } \\
\text { Motors } \\
\text { Ltd. }\end{array}$ \\
\hline R & .963 & .310 & .506 & .078 \\
\hline R Square & .928 & .096 & .256 & .006 \\
\hline $\begin{array}{l}\text { Adjusted R } \\
\text { Square }\end{array}$ & .904 & -.205 & -.487 & -.325 \\
\hline $\begin{array}{l}\text { Significance } \\
\text { Value }\end{array}$ & .008 & .611 & .662 & .901 \\
\hline F value & 38.05 & .320 & .345 & .018 \\
\hline
\end{tabular}

Source: Author's Computation

$\mathrm{H}_{04}$ : There is no significant impact of current ratio on share price.

Table V states that Maruti Suzuki India Ltd. share price and current ratio has highly positive correlation and also there is a positive correlation between share price and current ratio of Mahindra \& Mahindra Ltd., Hero MotoCorp Ltd. and Tata Motors Ltd. Significance value shows that share price of Maruti Suzuki India Ltd. has significant impact of Current ratio (Hypothesis is Rejected) while Tata Motors Ltd., Hero MotoCorp Ltd. and Mahindra \& Mahindra Ltd. share prices have no significant impact of current ratio (Hypothesis is accepted).

Accordingly, it can be said that share price of automobile companies has a significant impact of liquidity of the companies, at the same time degree of impact vary.

E. Impact of Book Value on Share Price of Selected Automobile Companies :

Table- VI : Result of Correlation for Book Value and Share Price

\begin{tabular}{|l|c|c|c|c|}
\hline Company & $\begin{array}{c}\text { Maruti } \\
\text { Suzuki } \\
\text { India } \\
\text { Ltd. }\end{array}$ & $\begin{array}{c}\text { Mahindra \& } \\
\text { Mahindra } \\
\text { Ltd. }\end{array}$ & $\begin{array}{c}\text { Hero } \\
\text { MotoCorp } \\
\text { Ltd. }\end{array}$ & $\begin{array}{c}\text { Tata } \\
\text { Motors } \\
\text { Ltd. }\end{array}$ \\
\hline R & .968 & .589 & .932 & .497 \\
\hline R Square & .936 & .347 & .868 & .247 \\
\hline $\begin{array}{l}\text { Adjusted R } \\
\text { Square }\end{array}$ & .915 & .129 & .824 & -.004 \\
\hline $\begin{array}{l}\text { Significance } \\
\text { Value }\end{array}$ & .007 & .296 & .021 & .394 \\
\hline F value & 44.00 & 1.592 & 19.70 & .968 \\
\hline
\end{tabular}

$\mathrm{H}_{05}$ : There is no significant impact of book value on share price.

Published By:

Blue Eyes Intelligence Engineering

\& Sciences Publication

DOI:10.35940/ijmh.F0648.024620

Journal Website: www.ijmh.org

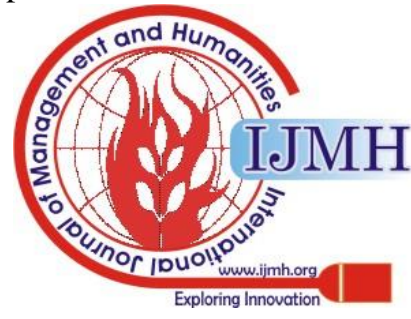




\section{Impact of Financial Variables on Share Price of Selected Indian Automobile Companies}

The results of Table VI concludes that Maruti Suzuki India Ltd. and Hero MotoCorp Ltd. share price and book value have highly positive correlation. Share price and book value of Mahindra \& Mahindra Ltd. and Tata Motors Ltd. are also positive correlated but not as high as Maruti Suzuki India Ltd. and Hero MotoCorp Ltd. Significance value shows that share price of Maruti Suzuki India Ltd. and Hero MotoCorp Ltd. has been impacted by the book value (Hypothesis rejected) but there is no significant impact of book value on share price of Mahindra \& Mahindra Ltd. and Tata Motors Ltd. (Hypothesis accepted).

So, it can be concluded that share price of automobile companies are effected by the book value per share of the companies but the degree of impact vary from company to company.

\section{CONCLUSION}

The main aim of this study is to find out whether the financial variables are one of the important determinants of market price of shares of automobile companies or not. The study mainly tried to establish a relationship between market price of shares and five other financial variables namely Net Profit Margin (NPM), Assets Turnover Ratio (ATR), Debt Ratio (DR) Current Ratio (CR), and Book Value per share (BVPS). On the basis of results of this study, it can be concluded that Maruti Suzuki India Ltd. share price has been impacted by all the selected financial variables except assets turnover ratio. In case of other companies, financial variables impact on share price vary company to company. Lastly, it can be concluded that investors should consider the financial variables while taking the decision of investment in stock market.

\section{REFERENCES}

1. Agirman E. and Yilmaz O. (2018), Value of Financial Ratios in Predicting Stock Retuns: A Study on Borsa Istanbul (BIST), Journal of Business, Economics and Finance, Vol. 7(2), pp. 191-199, ISSN 2146-7943.

2. Haque M.R., Datta R.K. and Rahman M.M. (2013), Financial Variables Having Significant Impact on Market Price of Shares, Research Journa of Finance and Accounting, Vol. 4(15), pp. 76-80, ISSN 2222-1697.

3. Kamar K. (2017), Analysis of the Effect of Return on Equity (ROE) and Debt to Equity Ratio (DER) on Stock Price on Cement Industry Listed in Indonesia Stock Exchange (Idx) in the Year of 2011-2015, IOSR Journal of Business and Management (IOSR-JBM), Vol. 19(5), pp. 66-76, ISSN: 2319-7668.

4. Lutfi M. and Arsitha J. (2016), The Analysis of Factors Affecting Price Earnings Ratio on the Company Shares Registered in Jakarta Islamic Index, Academic Journal of Economic Studies, Vol. 2(3), pp. 55-63, ISSN 2393-4913.

5. Meriç E., Kamışlı M. and Temizel F. (2017), Interactions among Stock Price and Financial Ratios: The Case of Turkish Banking Sector, Applied Economics and Finance, Vol. 4(6), pp. 107-115, ISSN 2332-7294.

6. Saeidi P. and Okhli A. (2012), Studying the Effect of Assets Return Rate on Stock Price of the Companies accepted in Tehran Stock Exchange, Business and Economic Horizons, Vol. 8(2), pp. 12-22, ISSN 1804-1205.

7. Wijaya J.A. (2015), The Effect of Financial Ratios toward Stock Returns among Indonesian Manufacturing Companies, iBuss Management, Vol. 3(2), pp. 261-271.

\section{AUTHORS PROFILE}

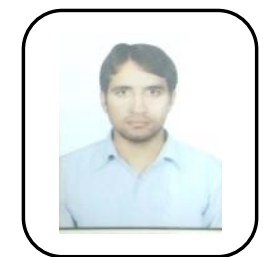

Dr. Rakesh Kumar, is an Assistant Professor in Accountancy and Law Department at Dayalbagh Educational Institute (Deemed University), Agra. His area of specialization is Reporting. His subjects of interest are Management Accounting, Financial Accounting, Corporate tax planning, etc. He has research interest in Financial reporting, International Financial Reporting Standards, IND AS, Climate change reporting, Stock market, Financial analysis, etc.

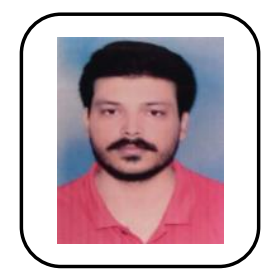

Ayushman, is a Ph.D. scholar in Accountancy \& Law Department at Dayalbagh Educational Institute (Deemed University), Agra. He also holds a Masters of Philosophy degree from the same institute. His interest areas of research are stock market, financial reporting, financial analysis, etc.

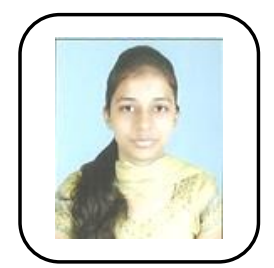

Rishika Agarwal, is a Ph.D. scholar in Accountancy and Law Department at Dayalbagh Educational Institute (Deemed University), Agra. She holds a Master's degree in Accountancy and Law from St. John's College, Agra. Her research interests center around the financial reporting, International Financial Reporting Standards, IND AS, financial analysis, etc.

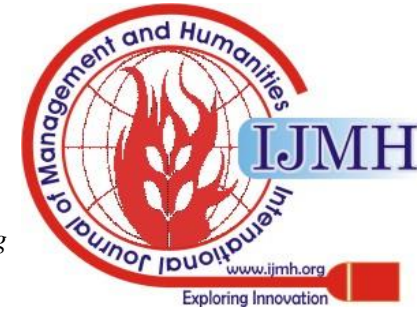

